\title{
Propensity to use global solutions of creative and aggressive accounting - in the light of accountants' opinions
}

\author{
Aleksandra Szewieczek ${ }^{1,}{ }^{*}$ and Patrycja Ostrowska $^{1}$ \\ ${ }^{1}$ University of Economics, College of Finance, 1 Maja 50, 40-287 Katowice, Poland
}

\begin{abstract}
Research background: The processes of globalization contributed to the unification of accounting principles through their standardization and harmonization. However, there is rapid and frequent permeation of innovative and complex transactions and as a result, the area and scale of implementation of creative and aggressive accounting practices are increasing. There is also a new issue of forensic audit, whose task is to prevent economic crime by mainly detecting financial crime and fraud. A research field that requires deepening is the analysis of the perception, understanding, and propensity of accountants to adopt creative and aggressive accounting solutions and their attitude toward forensic audit. Purpose of the article: The main purpose is to analyze the degree of knowledge and adoption of internationally known creative and aggressive accounting solutions and to investigate the propensity of people involved in accounting to commit fraud.

Methods: The article employed survey methods and techniques (within an accounting students' group and among accounting professionals) as well as literature analysis, synthesis, and inference.

Findings \& Value added: The results indicate that the degree of knowledge of creative accounting is the highest among the issues considered. The most important factors influencing the propensity to commit fraud are pressures caused by third parties (in particular superiors), financial benefits, and the fear of losing a job. Knowledge of the issues of forensic audit is low. It is necessary to conduct promotional activities to increase awareness of the issues studied and to shape appropriate ethical attitudes among accounting professionals.
\end{abstract}

Keywords: creative accounting; aggressive accounting; forensic audit; fraud; financial reports

JEL Classification: $M 40 ; M 41 ; M 49$

\footnotetext{
*Corresponding author: aleksandra.szewieczek@ue.katowice.pl
} 


\section{Introduction}

Over time and the development of both the domestic and international economy, financial reporting has become one of the most evolving areas of accounting. Through numerous changes, harmonization, and standardization, specialists have created rules and principles for the preparation of financial statements to maintain their comparability and usefulness for recipients, maintaining, among others, the principles of transparency, credibility, and reliability. According to the International Financial Reporting Standards (Commission regulation, 2008), the primary purpose of financial statements is to provide useful and reliable information about the entity to internal and external recipients.

Accounting trends such as creative and aggressive accounting have evolved along with the development of accounting. In addition, the term forensic audit has recently been coined. Over the years, there have been many pathologies related to the manipulation of results and financial data. These phenomena are emerging all over the world. For those events, activities that were defined as "creative accounting" and "aggressive accounting" have begun to be researched and observed in a more frequent and wider manner. These phenomena were initially described as "financial shenanigans." This concept was defined by H.M. Schilit as "acts or omissions to do so to conceal or distort the actual financial performance or financial condition of the entity." However, due to the growing number of such activities and their varied nature, the notions of creative and aggressive accounting have gradually been applied in the literature (Gut, 2006). Creative accounting is defined as the activities of persons responsible for the preparation of financial statements, consisting in presenting the economic situation in such a way as not to present the actual financial situation of the entity but using loopholes in the law regarding procedures, rules, and standards to transform data until the desired result is achieved. This requires creative and resourceful actions from people who prepare financial statements (Stępień, 2014).

Problems with perceiving various activities as creative accounting contributed to distinguishing its two dimensions - positive and negative. Creative accounting is viewed positively when the person who prepares financial statements creatively interprets and applies the rules in accordance with the law. Legal regulations do not fully apply to all the economic events that have occurred in practice, which results from delays in their adjustment, but also from the inability to regulate all practical aspects. Not only are therefore people applying legal provisions required to understand the regulations contained in the act, but also to interpret them appropriately and creatively to present their content in a reliable and clear manner in line with the law (Gut, 2006).

Creative accounting is also viewed in a negative manner, as a pathology in the financial market and as a crime related to manipulation, misappropriation, and fraud. Such initial terminology has been transformed over time into a separate concept of aggressive accounting, which deliberately misleads the recipient and goes beyond the limits stipulated by the law.

A key role in defining aggressive and creative accounting plays the distinction between the terms "error" and "fraud." National Standard on Auditing 240 (Krajowy Standard ..., pp. 9-10) characterizes these two concepts. "Accounting error" is an unintentional action caused, among others, by inadvertent omission of data or mistakes resulting from inattention or ignorance. In contrast, "fraud" is defined as the deliberate, intentional conduct to gain financial gain or to manipulate the recipient in a desired direction. It should be noted that the definition of "accounting fraud" overlaps with the area of activities of "aggressive accounting." However, "accounting error" should not be equated with both aggressive and creative accounting, as it is an unintended activity. Creative and aggressive accounting are always a deliberate behavior (Gut, 2008).

In the context of aggressive accounting increasingly often emerges the concept of forensic audit. When examining this area, first of all, the role of the financial data auditor should be 
defined. The statutory auditor carries out reviews and audits of financial statements to confirm or contradict the credibility of the audited financial statements. However, in accordance with the National Standard on Auditing 240 [Krajowy Standard ..., p. 3], the auditor is obliged to carry out activities related only to irregularities that materially distort the information presented in the financial statements. Meanwhile, the auditor should also consider distortions resulting from fraudulent financial reporting and misappropriation of assets. The auditor does not rule on the question of whether fraud has actually occurred (in the light of the law). They do not analyze whether incorrect information in the audited report is the result of deliberate actions or accidental errors. Due to the lack of an obligation to detect financial crime, a new sub-field of audit was created, which is forensic audit.

So far, the literature on this issue is scarce. Forensic audit is primarily designed to counteract economic crime, and in particular to detect corruption, misappropriation, fraud, and financial crime, regardless of the ownership structure of the audited enterprise or its sectoral affiliation. Forensic audit mainly uses methods adopted in financial auditing, but also forensic methods. The use of forensic methods distinguishes this type of audit, as sometimes financial audit methods are not sufficient to detect fraud. Forensics is the field of science which adopts methods used to detect, identify, and collect evidence in order to resolve a case. Due to the use of these non-standard methods by the auditor, similarities can be found with the profession of an investigator. This type of audit is carried out by people qualified in the studied areas, for example with the ACFE certificate (Association of Certified Fraud Examiners). Forensic audit detects and prevents financial crime and allows to identify the perpetrators of crimes. The most frequently used methods in the field of forensics are: examination of documents, interrogation, expert opinions, visual inspection, and criminal analysis (Kadej, 2017).

Falsification of financial statements is an event that is becoming increasingly common in a market economy. The so-called "white-collar crimes" have been occurring almost from the very beginning of accounting. However, over time, this phenomenon began to pose an increasing threat. The literature distinguishes "seven main goals of fraud" (Wąsowski, 2010):

1. Overstating the generated profit or reducing losses.

2. Hiding incurred losses.

3. Manipulating financial indicators used in financial analysis.

4. Acquiring capital from lenders that could not be obtained without manipulating the data.

5. Improving the results for the attainment of managerial goals.

6. Enhancing the image to attract and retain investors as well as credit and loan institutions.

7. Concealing the true financial position of the entity during stakeholder control and creating a positive image of the enterprise (Surdykowska (Ed.), 2005).

Despite the fact that the subject of financial fraud has extensively been studied for many years, it still cannot be completely prevented. D. Cressey, who conducted research on fraudulent financial reporting, created the concept of the so-called the "Fraud Triangle" many years ago. This concept was developed to justify the essence of fraud. It identifies three basic factors which, taken together, almost always ensure the occurrence of accounting fraud. These are: the presence of pressure (motivation), opportunities, and rationalization (selfjustification). What is particularly important, the elimination of at least one of these factors will most likely exclude the emergence of accounting fraud (Żukowska-Kalita, 2017; Latan et al., 2018).

In addition to accounting standards and principles, ethics, i.e., the science of morality, plays an important role in creating financial information (Baud et al., 2019). The concept of ethics has been developing naturally in the field of business for many years (Cragg, 1997). It depends to a large extent on the person dealing with accounting and finance whether they will take moral or unethical actions and commit a document falsification. The sense of inner 
control (self-control) has a substantial impact in this respect, which significantly affects not only unethical behavior but also the intention to reveal irregularities (Wahyuni, et al., 2021). Another factor that significantly shapes ethical attitudes in professional activity is conducting educational activities as part of study programs (Odar et al., 2017; Okougbo et al., 2021). For the proper performance of accounting activities, the code of professional ethics presents several values that are considered moral values necessary to act in an ethical manner. These include: honesty, reliability, objectivity, courtesy, respect, and social responsibility. Furthermore, the code of ethics contains guidelines on how to deal with the occurring conflicts of interest and with ethical dilemmas (Kodeks zawodowej etyki w rachunkowości, 2012; Payne et al., 2019]. Thanks to the analysis of areas of illegal accounting activities, it is possible to identify preventive measures that counteract financial crime, and above all, reduce the propensity of accountants to commit fraud. Lack of pressure (including time) from third parties, especially those holding a higher position, may have a positive effect on counteracting financial crime (Koh et al., 2018). In addition, it is necessary to indicate the lack of excessive expectations and various types of temptation (including incentives through the possibility of obtaining financial benefits, bonuses, salary increases or professional promotions). Moreover, promoting ethical values, conducting training in the field of suspicious fraud symptoms may have a positive effect on counteracting aggressive accounting practices (Okougbo et al., 2021), and generally reduce financial scandals in the area of finance (Kowaleski et al., 2020) The use of negative accounting practices is also caused by the desire to achieve individual and personal benefits, as well as the protection of one's own reputation, also within the position in the organization (Baud et al., 2019). Employee motivation system in the form of rewards and penalties for financial results achieved in a short period of time may cause excessive willingness to reach good results and contribute to the search for negative solutions (Wąsowski, 2010). Accounting fraud may also be influenced by other factors such as age or gender, as well as corporate conditions, including the form of ownership of the enterprise (Guiso et al., 2015; Nguyen et al., 2021). The knowledge of the person responsible for drawing up accounting documents is also important, as the accounting profession requires constant updating of knowledge about the changing regulations and requirements of economic life.

\section{Methods}

The main goal of the study was to find out about the level of knowledge of creative and aggressive accounting by people professionally involved in accounting, as well as to investigate their propensity to commit fraud. The thesis was verified that activities related to creative and aggressive accounting are known and used by accountants for shaping financial statements. The empirical study was carried out by means of a survey questionnaire study. The questionnaire was addressed to people working in the profession related to accounting, students of related faculties (master's studies), and statutory auditors. Due to the sensitivity of the topic under study, the survey was conducted in an anonymous form in order to obtain reliable results. The survey consisted of 23 single and multiple choice questions, and the Google Form questionnaire was used to conduct it. As part of the questions, four extensive questions were also included, of a case study nature, which were aimed at examining the propensity to commit fraud. The research group was divided by gender, education level, and job seniority. Feedback from 82 individuals was received. The group of respondents consisted of $73 \%$ of women and $27 \%$ of men, which is typical due to the strong feminization of the accounting profession in Poland. Furthermore, almost all respondents have higher education or are in the process of completing it (96\%). Moreover, the research group was comprised of the following:

$>20.7 \%$ of students of faculties related to accounting, 
$>22.0 \%$ of students working in the accounting profession,

$>7.3 \%$ of people working in the accounting profession with less than one year of work experience,

$>25.6 \%$ of people working in the accounting profession with one - five years of work experience,

$>24.4 \%$ of people working in the accounting profession with more than five years of work experience.

When analyzing the responses, attention was also paid to the analysis of the relationship between the demographic and social affiliation of the respondents and their responses. Various statistical measures were also used, including: arithmetic mean, Cramér's V coefficient, $\mathrm{Chi}^{2}$ statistic $\left(\chi^{2}\right)$.

\section{Results}

The conducted questionnaire research allowed us to examine the scope of knowledge and awareness related to fraud and the propensity of accountants to commit it. The data received showed that $96 \%$ of the respondents were familiar with the definition of creative accounting. The following responses were indicated as sources of knowledge: school $-84 \%$; work $46 \%$, friends or news $-28 \%$. On the other hand, the concept of aggressive accounting was not familiar to $24 \%$ of respondents, which allows the conclusion that this concept is commonly known, although among a slightly smaller group of people. The respondents learnt about this concept from: school $-68 \%$; work $-21 \%$; and friends or news $-13 \%$.

In terms of knowledge whatever the concepts of aggressive and creative accounting can be equated, the answer was mostly negative (69.5\% of the respondents). $24.4 \%$ did not know the answer to this question, and $6.1 \%$ stated that these concepts are equated with each other.

Among the respondents, the self-assessment of knowledge about creative accounting was as follows: no knowledge at all $-7 \%$; poor $-40 \%$, sufficient $-35 \%$, good $-16 \%$, very good $-1 \%$. On the other hand, when it comes to aggressive accounting, no knowledge at all $20 \%$; poor $-43 \%$; sufficient $-23 \%$; and good $-15 \%$.

Then, two questions were prepared to check whether the research group was able to identify the basic difference between the discussed concepts. Responses to the question whether the activities related to creative accounting are in line with the law were as follows: yes $-59.8 \%$; only some $-26.8 \%$; no $-8.5 \%$; I do not know $-4.9 \%$. On the other hand, the corresponding question of whether the aggressive accounting practices are legal, the following results were obtained: no $-50 \%$; some activities $-23.2 \%$; yes $-4.9 \%$; I do not know $-22 \%$. Furthermore, it was checked whether the research group had encountered manipulations of financial data in professional practice. The structure of the responses obtained was as follows: no $-48.8 \%$; yes $-35.4 \%$; only with regard to creative accounting; yes $-0 \%$, only with regard to aggressive accounting; with regard to both creative and aggressive accounting $-15.9 \%$. Then, an analysis of the relationship between the length of service and the response given was carried out. $\mathrm{Chi}^{2}$ statistic was calculated, which amounted to 14.3 and the Cramér V-correlation coefficient, which value was $72.34 \%$.

In addition, an attempt was made to identify the factors that are the most common reasons for falsifying financial statements. The obtained results are presented in Table 1 . 
Table 1. Most common causes of financial fraud.

\begin{tabular}{|l|c|}
\hline \multicolumn{1}{|c|}{ Specified causes } & Responses (\%) \\
\hline $\begin{array}{l}\text { Willingness to improve the financial situation - overstating } \\
\text { profits }\end{array}$ & $83.54 \%$ \\
\hline Concealing the enterprise's current financial situation & $54.43 \%$ \\
\hline Need for obtaining additional capital & $48.10 \%$ \\
\hline Understating enterprise's losses & $46.84 \%$ \\
\hline Temptation related to possible promotion or bonus & $37.97 \%$ \\
\hline Fear of losing the job & $32.91 \%$ \\
\hline Human nature (greed) & $18.99 \%$ \\
\hline Possible financial crisis & $13.92 \%$ \\
\hline Fierce competition & $7.59 \%$ \\
\hline
\end{tabular}

Source: Own study.

The research also verified the propensity to commit fraud. It turns out that the aspect of the reporting lines dominates here, but also the performance of activities that are in compliance with the law, i.e., in the area of creative accounting. Yet, actions forced by the reporting line but carried out as aggressive accounting were ranked second.

Next, the factor that influenced the surveyed group of respondents is the possibility of obtaining significant financial benefits. This factor had a greater impact on the research group than the possibility of obtaining a bonus or salary increase (it is assumed that the degree of these benefits is lower). About $6 \%$ of the research group would undertake an activity related to aggressive accounting for fear of losing their job. However, none of the respondents would undertake such activities in exchange for a professional promotion. A detailed summary of the data is presented in Figure 1.

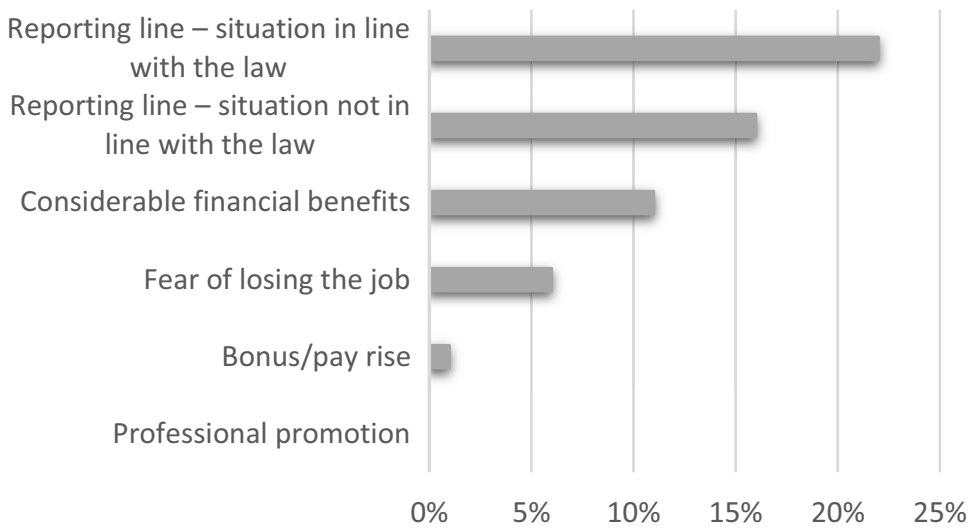

Figure 1. Influence of the indicated factors on the propensity of the research group to commit fraud.

Source: Own study.

The popularity of the forensic audit issue among the research group was also checked. $56 \%$ of the respondents did not know about the concept, while $44 \%$ replied affirmatively. Moreover, the respondents assessed their knowledge in this field as follows: no knowledge at all $-41 \%$; poor $-28 \%$; sufficient $-18 \%$; good $-11 \%$; very good $-1 \%$.

Four case studies were worked out for the purpose of in-depth research on the propensity of accountants to commit fraud. The first was: "If it were possible to achieve significant financial benefits by slightly modifying some financial data, but there would be a minimal probability that someone would notice it, would you be willing to take such action?" The 
purpose of this question was to check how the willingness to achieve financial benefits can influence the decisions made by accountants. The respondents chose the answers as follows: no $-66 \%$; sometimes $-5 \%$; yes $-4 \%$; I do not know $-26 \%$.

Case study 2 was as follows: "The owner of the enterprise asks you, as a person dealing with bookkeeping, not to create a provision for retirement benefits that will take place next year, because they do not want to underestimate the already low financial profit. This action will not be detrimental to other people and will not cause a significant difference in the presented financial data. What would you do it in this situation?" This question was aimed at examining whether a bonus, promotion or reporting line could influence the respondent's behavior. Figure 2 shows the results obtained.

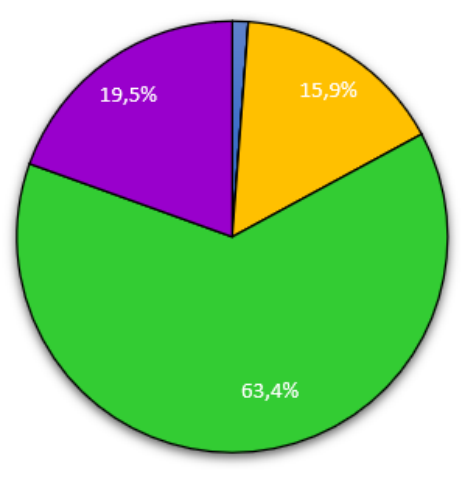

I would agree to the supervisor's proposal in exchange for a bonus or a pay rise

$\square$ I would agree to the supervisor's proposal in exchange for a promotion

$\square$ I would agree to the supervisor's proposal due to the reporting line

口I would analyze the problem and suggest a different, more favorable solution

- I would categorically disagree

Figure 2. Structure of responses obtained - case study 2.

Source: Own study.

Case study 3 checked how the surveyed group of respondents would have acted in the indicated situation, if further possibility of continuing work in this entity depended on this decision. The question was as follows: "Let us assume that you are a person working in a given enterprise who draws up accounting documents, including financial statements, but the person responsible and signing for them is your supervisor. The owner of the company asks you to change the sign (+/-) of one of the items in the cash flow statement to improve creditworthiness. The condition for the possibility of continuing work in this entity is the performance of the required activity. What would you do, bearing in mind that the responsibility for this activity would be borne by your superior, because only they sign the document?" Figure 3 shows the results obtained.

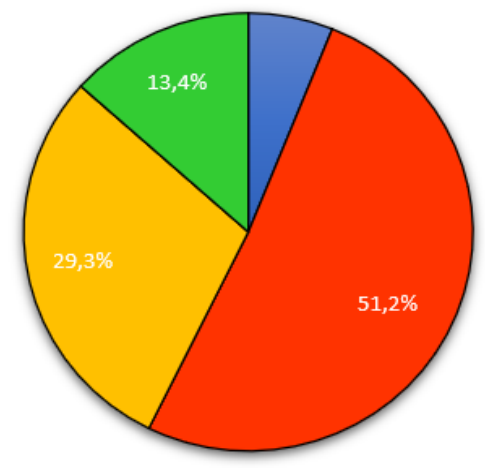

$\square$ I would fulfill the enterprise owner's request for fear of losing my job

$\square$ I would notify my supervisor about the owner's request

I would refuse to do as requested

I would resign from my job

Figure 3. Structure of responses obtained - case study 3.

Source: Own study. 
The last case study was as follows: "Due to the technological progress, the chief accountant asks you to make a write-off for permanent impairment of a fixed asset of considerable value. At the same time, the supervisor of the entity expects costs to be overestimated in a given reporting period. Will you follow the chief accountant's order?"

This was a loaded question, as the activity of making a write-off for the value of the fixed asset was compiled with the expectation of the superior to overestimate costs. Pursuant to the Accounting Act, this activity is lawful and would be required to take place even without the supervisor's expectations [Journal of Laws No. of 2021, item 217]. Due to the materiality and occasional nature of this business operation, it is usually conducted at least under the supervision of the chief accountant. The structure of the obtained responses is presented in Figure 4.

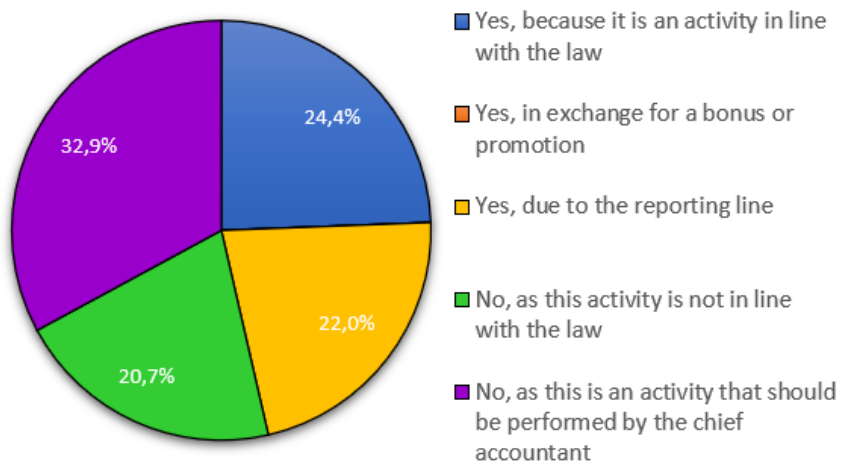

Figure 4. Structure of responses obtained - case study 4.

Source: Own study.

\section{Discussion}

When examining the issues of general knowledge of creative and aggressive accounting in the accounting environment, it can be concluded that its level is high, although the creative accounting is better recognized. Among the respondents, only $2 \%$ were not familiar with the concept of creative accounting, while in relation to the concept of aggressive accounting it was already $24 \%$. This trend is obviously maintained in terms of detailed knowledge of these two areas $(7 \%$ in the area of creative accounting and $20 \%$ in the area of aggressive accounting, respectively). In the case of both surveyed areas, the majority of respondents indicated that they acquired knowledge on these topics while studying at school or university. On the other hand, the respondents also more often dealt with creative rather than aggressive accounting when working in the profession.

A key point, however, is that the research showed a lack of knowledge about these phenomena in the accounting environment. This is emphasized by the self-assessment of knowledge in the field of creative accounting, for which the vast majority of respondents assessed this level as poor (40\%). Similarly, in the field of aggressive accounting, the selfassessment of the poor level of awareness dominated (53\%). The dominant reasons for taking actions related to creative and aggressive accounting are various forms of improving the image of the enterprise's financial and economic standing, also in order to limit the amount of shown losses or to obtain foreign capital. It can be concluded that the picture of the financial situation of an entity plays an important role for attracting new investors and capital providers or for maintaining the existing ones. Meanwhile, personal reasons (career promotions, job security, greed) of people implementing these activities are shifting to the background the ranking of fraud causes. 
Despite the fact that the majority of the research group did not show a propensity to commit fraud, the factor that the most influences the commission of negative accounting practices is the reporting line among the respondents. This factor can be classified as pressure or influence from people holding a higher position than the respondents. However, when comparing the effect of the reporting line in terms of compliance with the law, as might be expected, a larger group would comply with the command to act in accordance with the law.

The research also showed that the length of service of the research group affects the answers provided. It can clearly be seen that experience influences certain attitudes, habits, and knowledge. This is because the respondents who have been working in the profession for more than five years often dealt with the activities of creative and aggressive accounting compared to other groups. Certain attitudes are formed among such groups that have professional experience. Research indicated that people with longer work experience, assuming more professional experience, are not convinced that audited financial statements are definitely a reliable source of information. This may result from previous experiences. On the other hand, students perceive the audited financial statements as a fully reliable source of data.

It is also interesting that people who have worked for more than five years represent the largest proportion of the group that has not heard about aggressive accounting. It can be assumed that it results from the already created habits and the development of the concept of aggressive accounting. As indicated above, aggressive accounting can also be viewed as a negative aspect of creative accounting. However, one's habits should not be confused with the lack of constant updating of professional knowledge. Accountants are a profession that is required to constantly expand their knowledge and such activities can be found in the study group. This is confirmed by the fact that among the respondents who have been familiar with forensic audit, there are mainly people working in the profession for over one year.

The conducted research allowed for a positive assessment of the development of the accounting profession, which constantly updates the knowledge with regard to changes in the economic environment and correctly identifies new phenomena in accounting. It can also be confirmed that the trust placed in the profession is justified. Ethical standards are respected, and illegal activities are not widely applied and are met with resistance. Thus, professional accountants are reliable and credible people. Nevertheless, the incentives, premises and restrictions in practice, which may constitute a temptation to unethical attitudes, are an important factor in exercising constant supervision over the profession, including by raising awareness of the risks and ethical principles. The phenomenon of introducing new concepts into accounting can also be observed, and their slower, natural acquisition by people who have already completed the one stage of education. It is also important to deepen the research on accounting intentions and the phenomenon of forensic audit.

\section{References:}

1. Baud, C., Brivot, M., \& Himick, D. (2021). Accounting Ethics and the Fragmentation of Value. Journal of Business Ethics, 168, 373-387.

2. Commission regulation (EC) No 1126/2008 of 3 November 2008 adopting certain international accounting standards in accordance with Regulation (EC) No 1606/2002 of the European Parliament and of the Council, 5-8. https://eur-lex.europa.eu/legalcontent/EN/TXT/PDF/?uri=CELEX:32008R1126\&from=pl

3. Cragg, W. (1997). Teaching Business Ethics: The Role of Ethics in Business and in Business Education. Journal of Business Ethics, 16, 231-245.

4. Guiso, L., Sapienza, P., \& Zingales, L. (2015). The value of corporate culture. Journal of Financial Economics, 117(1), 60-76. 
5. Gut, P. (2006). Kreatywna księgowość a fatszowanie sprawozdań finansowych, C.H. Beck, Warszawa.

6. Kadej, A. (2017). Wybrane kryminalistyczne metody śledcze-możliwość wykorzystania w audycie śledczym. Studia i Prace Kolegium Zarządzania i Finansów/Szkoła Główna Handlowa, (154), 35-51.

7. Kodeks zawodowej etyki w rachunkowości (2012). Stowarzyszenie Księgowych w Polsce, Warszawa.

8. Koh, H., Scully, G., \& Woodliff, D. (2018). Can Anticipating Time Pressure Reduce the Likelihood of Unethical Behaviour Occurring ? Journal of Business Ethics, 153, $197-$ 213.

9. Kowaleski, Z., T., Sutherland, A., G., \& Vetter, F., W. (2020). Can ethics be taught? Evidence from securities exams and investment adviser misconduct. Journal of Financial Economics, 138(1), 159-175.

10. Krajowy Standard Rewizji Finansowej nr 240. (2015). Odpowiedzialność Biegłego Rewidenta podczas badania sprawozdań finansowych dotyczacych oszustw, załącznik nr 1.5 do uchwały nr 2783/52/2015 Krajowej Rady Biegłych Rewidentów z dnia 10 lutego 2015 r. https://www.pibr.org.pl/assets/file/1121,KRBR-uchwala-2783-52-2015wszystkie-zalaczniki.pdf

11. Latan, H., Jabbour, C., \& Jabbour A. (2019). Whistleblowing Triangle: Framework and Empirical Evidence. Journal of Business Ethics, 160, 189-204.

12. Nguyen, L. A., Dellaportas, S., Vesty, G. M., Pham, V. A. T., Jandug, L. \& Tsahuridu, E. (2021). The influence of organisational culture on corporate accountants' ethical judgement and ethical intention in Vietnam. Accounting, Auditing \& Accountability Journal, ahead-of-print.

13. Odar, M., Jerman, M., Jamnik, A., \& Kavcic, S. (2017). Accountants' ethical perceptions from several perspectives: evidence from Slovenia. Economic Research-Ekonomska Istraživanja, 30(1), 1785-1803.

14. Okougbo, P., O., Okike, N.,, E., \& Alao A. (2021). Accounting ethics education and the ethical awareness of undergraduates: an experimental study. Accounting Education, 30(3), 258-276.

15. Payne, D., Corey, C., Raiborn, C., \& Zingoni, M. (2019). An applied code of ethics model for decision-making in the accouting profession. Management Research Review, 43(9), 1117-1134.

16. Stępień, K. (2014). Polityka rachunkowości w kontekście rachunkowości kreatywnej. Studia Ekonomiczne. Uniwersytet Ekonomiczny w Katowicach, 201, 315-317.

17. Surdykowska, S. (2005). (Ed.). Rachunkowość kreatywna a oszustwa księgowe, Wyższa Szkoła Biznesu w Dąbrowie Górniczej, Dąbrowa Górnicza.

18. Ustawa z dnia 29 września 1994 r. o rachunkowości (2021). Tekst jednolity: Dz. U. z 2021 poz. 217. (Journal of Laws No. of 2021, item 217).

19. Zukowska-Kalita, J. (2017). Symptomy oszustw w sprawozdaniach finansowych i ich identyfikacja w procesie badania sprawozdania finansowego przez biegłego rewidenta. Zeszyt Naukowy, Kolegium Zarządzania i Finansów, 154, Oficyna Wydawnicza SGH, 59-61.

20. Wahyuni, L., Chariri, A., \& Yuyetta, E., A. (2021). Whistleblowing intention: Theory of planned behavior perspectives. The Journal of Asian Finance, Economics, and Business, 8(1), 335-341.

21. Wąsowski, W. (2010). Kreatywna rachunkowość - Fatszowanie sprawozdań finansowych, DIFIN, Warszawa. 